\title{
Democracy Under One-Party Rule?
}

A Fresh Look at Direct Village and Township Elections in the PRC

\section{Gunter Schubert}

\section{OpenEdition}

\section{Journals}

Édition électronique

URL : http://journals.openedition.org/chinaperspectives/256

DOI : $10.4000 /$ chinaperspectives. 256

ISSN : 1996-4617

Éditeur

Centre d'étude français sur la Chine contemporaine

Édition imprimée

Date de publication : 15 avril 2003

ISSN : 2070-3449

\section{Référence électronique}

Gunter Schubert, " Democracy Under One-Party Rule? », China Perspectives [En ligne], 46 | march-april 2003, mis en ligne le 23 novembre 2006, consulté le 10 décembre 2020. URL : http://

journals.openedition.org/chinaperspectives/256 ; DOI : https://doi.org/10.4000/chinaperspectives. 256

Ce document a été généré automatiquement le 10 décembre 2020.

(c) All rights reserved 


\title{
Democracy Under One-Party Rule?
}

\author{
A Fresh Look at Direct Village and Township Elections in the PRC
}

\author{
Gunter Schubert
}

1 The democratisation of the PRC's political system continues to be one of the most important issues in contemporary China-watching and research ${ }^{1}$. Although the empirical findings urge us to be very careful in predicting a democratic transition any time soon, most experts seem to be optimistic-at least-when discussing the long-term consequences of the Chinese reform process: Economic development, social stratification, political decentralisation, the rise of social movements, world market integration, the influence of the Internet and, last but not least, China's quest for international respect are all considered factors that contribute to the demise of authoritarian one-party rule. Certainly enough, these China scholars usually do not dare to develop scenarios of regime transformation in the $\mathrm{PRC}^{2}$, since this depends on a whole set of variables and interlinkage effects that cannot be seriously pre-calculated. However, there still seems to be a common understanding that in the end the PRC will not be able to withstand the victory of liberalism and democracy. Consequently, 'socialism with Chinese characteristics' is mainly regarded as a poor ideology that can never constitute an alternative path to (or even be an alternative model of) modernity as the Communist leadership is suggesting. In spite of much analytical fine-tuning in the China field over the past decade, liberal democracy is still the epistemological benchmark of most Western research on political system reform in the PRC that even those scholars tending to be sceptical or even pessimist on the short and medium-term perspectives for Chinese democracy ${ }^{3}$ cannot do without. To put it in less provocative or 'teleological terms': No China scholar can think of long-term stability in China without a comprehensive horizontal and vertical democratisation of the PRC's political system and the end of Communist one-party rule. ${ }^{4}$

2 In much Western research, ${ }^{5}$ China's reform policies are conceived of as a gigantic repair project in order to correct the mistakes and aberrations of Maoism. This is accompanied by the implicit viewpoint that the PRC's political system and society are structurally instable and prone to crisis, because the Communist regime sticks uncompromisingly to one-party rule. ${ }^{6}$ For example, China scholars in the West agree 
that the Peking government's attempt to establish a system of law to protect each citizen's constitutional rights-although going in the right direction-is doomed to failure, as long as the Communist Party (CP) claims the final say on right or wrong for itself. ${ }^{7}$ Although progress in the codification and application of laws is not ignored, most China scholars in the West dismiss these reform endeavours and demand true 'rule of law' in China. At the same time, however, they turn away from the interesting question-to what degree the $\mathrm{CP}$ actually has gained new and rather sustainable legitimacy by the introduction of 'rule by law' only. As a matter of fact, the question of sustainable legitimacy-building through institutional adaptiveness and flexibility of the Party has hardly been broached in the China field.

3 The same critique can be directed at other political reforms that are often dismissed as 'disguised authoritarianism'. The latter is certainly true for the mainstream verdict on direct village elections in the PRC, which have only recently gained more scholarly attention (see below). This said, I want to formulate three hypotheses: 1. Village elections do contribute substantially to the rise of democratic politics in China; 2 . Direct elections at the local level-possibly extended to the townships and counties soon-do not necessarily challenge Communist one-party rule; and 3. Local direct elections will generate new legitimacy for the Communist Party and stabilise the whole political system instead of debilitating it. Therefore, the CP's power monopoly can and will be sustained for a long time yet.

Directly attached to the three hypotheses listed above is the assumption that we need a change of perspective in the China field to understand the functioning and the stability of the PRC's political system better. Too much is lost sight of or is perceived in a distorted way, if the noticeable change of the PRC's political system is understood as an incremental and unavoidable transition from authoritarianism to (more or less) Western-style democracy. Maybe we are facing here the gradual evolution of a relatively stable multi-level system that binds together some essential elements of the Western model of competitive democracy with one-party rule. Tensions and frictions in such a system would not be proof of systemic instability, but of internal negotiation processes that actually strengthen the whole setting.

This also means that we must not measure the 'democratic substance' and stability of the PRC's political system against any ideal type (Idealtypus) of (Western) democratic theory but by carefully analysing the internal innovation potentials of this system-i.e. its institutional flexibility and adaptability - to generate elite accountability and regime legitimacy. 'Chinese Democracy' in this restricted sense might be defined as fair and competitive elections at the local level embedded in a system of one-party rule which is generally accepted by the people. Such a concept does not ignore the possibility of overall regime transformation (set out in Western concepts of liberal democracy) some time in the future. However, it assumes that democratic participation in the PRC at the lower administrative levels is possible without automatically putting the CP's power monopoly into jeopardy, but even stabilising it. How sustainable such a system is, depends on the CP's ability to use its 'gained time' to proceed successfully with the implementation of economic and social reforms. However, as long as local elections are democratic in the above-defined sense, the $\mathrm{CP}$ may gain enough time for implementing those reforms. The following sections draw on the empirical data of direct village and township elections gathered so far in an attempt to verify this assumption. 
Village elections

Since the passing of the experimental Organic Law of Village Committees in 1987, free and direct elections of village committees have a firm legal foundation in the PRC. According to the Organic Law, these institutions administer all public affairs in the villages, provide public welfare, engage in dispute settlement, take care of public security and transmit villagers' opinions, demands and proposals to the government. Moreover, village committees implement government policies and regulations, most importantly the fulfilment of grain delivery quotas, the promotion of local economic development on the basis of the rural household responsibility system, and official birth-planning. Each village committee consists of three to seven members, among them a village director and a deputy, who are elected every three years.

7 The Organic Law was highly contested within the CP from the very beginning of discussion about it in the mid-1980s. Its opponents-among them many local cadreswere afraid of a dangerous politicisation of China's villages and a further decline of party control over the countryside. At the same time, the supporters of the law pointed at the necessity to strengthen village self-rule and autonomy in order to promote rural development and to reconsolidate the shattered party legitimacy at the grassroots level. According to them, only if peasants gained a right to directly participate in local politics, could cadre corruption be reduced, the peasant-Party relationship restored and rural stability upheld. Finally, these forces landed a victory. In the following years, the Party leadership took a wait-and-see approach, with warning voices never disappearing from the scene. ${ }^{8}$ Ten years after its promulgation, the Organic Law was evaluated by the Fifteenth Party Congress in September 1997. In November 1998, the National People's Congress passed a revised version. ${ }^{9}$ Since then, direct village elections have been compulsory nation-wide.

8 According to information from officials of the Ministry of Civil Affairs (MCA), direct elections for village committees have taken place in China's approximately 900,000 villages at least once since implementation began in the late $1980 \mathrm{~s}^{10}$ Some provinces like Zhejiang, Fujian and Hebei, which started very early with elections, have already seen several rounds of balloting. Others like Guangdong and Yunnan have started only recently to experiment with direct elections at the village level. The case studies presented by China scholars so far (comprising only a sample of some hundred villages though) tell very different success stories of this government reform policy. As a matter of fact, success is a very ambivalent notion here, as far as the CP's perspective is concerned. In some areas, where local cadres have illegally interfered in the election process (e.g. by violating nomination regulations, imposing candidates or manipulating election results), the Party often gets into trouble: At best peasants, become discouraged about taking part in the ballot. Sometimes, however, they start to engage in local protests with devastating consequences for the Party's legitimacy. But also in those places, where elections have been implemented fairly well, things can turn out badly for the Party. Since the peasants feel empowered by the right to vote, they are ready to claim better implementation of the Organic Law and more political participation after the elections. In both cases, the Party's core aims to enhance government efficiency and to stabilise its rule seem to be compromised considerably. Indeed, by promoting direct elections, the Party might have installed a Trojan horse in the villages, setting free forces that could soon shake the very foundations of the CP regime. However, there are also signs that the government has succeeded in achieving 
more efficiency and legitimacy in other parts of rural China. Summarising the main findings of empirical research on Chinese village elections, the following picture can be drawn: ${ }^{11}$

- The procedural quality of direct village elections in the PRC has seen remarkable improvements during the past decade. Many provinces have passed new implementation guidelines since the revision of the Organic Law in 1998, covering issues such as free nomination of candidates, secret voting and transparent ballot counting. They also have given villagers the right to recall elected cadres in case of criminal acts while in office and put under punishment any violations of the Organic Law. ${ }^{12}$ Furthermore, the national standardisation of these guidelines is pushed forward by bureaucratic networking among the different units of the Ministry of Civil Affairs. Meanwhile, China scholars have found a significant relationship between the quality of elections on the one hand and the degree of political awareness of the peasants on the other: The better elections are implemented, the stronger the inclination to participate in them. Although China lacks any tradition of institutionalised democracy, it apparently follows the rule that competitivity and fairness of elections enhance the will to participate. ${ }^{13}$

- At least in some parts of China, the introduction of direct elections has gradually changed the relationship between the peasants and their village committees. Elected cadres need the support of the villagers to stay in office. At the same time, democratically elected village committees are equipped with new political legitimacy that they can use either for carrying through the policy directives coming from above or for the formation of resistance against the township and county governments on behalf of their electorate. Therefore, the position of the village committees has become quite complex, although according to the Organic Law they are still under the guidance of the Party. How the village committee is making use of this position and how this is changing local power configurations is one of the most intriguing issues of the empirical research currently being undertaken in China. Apparently, in some places the village committees have become more resistant to the township government, while in others conflicts between these two levels could be reduced. ${ }^{14}$

- At the same time, the village Party secretary may lose his former authority as the dominant factor in local politics. He now faces a democratically-elected village director who might challenge him on the grounds of representing the people's true interests. This forces the Party to bind its nomination of village secretaries to some form of public endorsement. In fact, the Party experiments with different methods to gain the villagers' consent here. For example, a so-called 'two-ballot-system' has been introduced in some parts of China allowing all villagers a recommendation vote for the post of Party secretary. ${ }^{15}$ Only if the Party's candidate gains a majority of the vote, is he/she given the final okay to assume office. In most cases, only those candidates promoted as Party secretaries have already won the ballot for head of the village committee. Then the Party can take advantage of the village director's democratic legitimacy and is able to avoid a power conflict between the Party and civilian branches of local government. Some scholars have stated that this specific adaptation to a changed political environment in the villages might trigger a process of intra-party democratisation that would have positive consequences for the further development of local democracy in China. Although such a statement might be far too optimistic, it is observable that the Party is trying to secure its power monopoly by gradually introducing more transparency and democratic procedures to intra-party decision-making concerning the recruitment of local office-holders. ${ }^{16}$

- Political participation has made the peasants more inclined to 'contact' their village committees after the elections in order to make the committees fight for their personal or 
collective interests. Therefore, elections have sharpened political awareness in the countryside. This is proven by a new culture of 'rightful resistance' vis-à-vis the cadre bureaucracy: Peasants know their rights and are ready to claim them against those local officials, who oppose direct elections and the containment of Party authority in rural China. Petitions, demonstrations and sit-ins, but also violence are well-chosen strategies of 'rightful resisters' to secure fair elections and rules-based cadre behaviour. If necessary, their criticism and complaints are pushed up to the national level. This may suggest that peasants have developed a rudimentary civic conscience. It is only rudimentary, because they do not claim a general right of participation derived from the state Constitution, but insist only on those limited rights that have been given to them at the lowest administrative level.

However, by doing this they implicitly insist on a contractual relationship between the Party and the peasants. Therefore, 'rightful resistance' has both strengthened and shaken the stability of Communist rule in the countryside-depending on the way the Party has reacted to the resisters. ${ }^{17}$

9 As was already emphasised, these are only provisional results that are certainly not representative of every Chinese village. There can hardly be a doubt of the fact that in the overwhelming majority of the villages with direct elections the Party clearly dominates the political process. Moreover, reports on serious conflicts between elected village committees on the one hand and village Party secretaries and township governments on the other paralysing the village administration are abundant. The core problem here is who has the final decision-making power. ${ }^{18}$ The Organic Law is rather ambivalent on this issue: On the one hand, the Party is leading the village committee, on the other hand it has to adhere to the principle of village self-rule and autonomy. ${ }^{19}$ Apart from this, elections are frequently rigged by powerful Party secretaries who are supported by township governments to win the post of village committee director for themselves or to install an obedient follower of party and township government directives. The problematic influence of clan organisations and powerful local networks of cadres and entrepreneurs engaging in vote-buying and technical manipulations of elections also belong to the everyday picture of direct village elections in China. ${ }^{20}$

However, much speaks for the hypothesis that all depends on time and practice: The more often elections take place in a village, the more competitive and fair they tend to be-and the more politically aware and active become the peasants. Since the CP decided at its Fifteenth Party Congress in 1997 to proceed with the nationwide institutionalisation of direct village elections, there is quite some reason to be optimistic about the positive development of this reform policy. The general assessment of direct village elections is also positive for many cadres supporting Communist one-party rule. Obviously, many Party leaders and local officials see them as conducive to rural stability and legitimacy-building. This might also explain the Party leadership's long tolerance of those provincial and local cadres who started experimenting with direct township elections as early as 1998 (see below). This tolerance seemed to run out with CP Central Committee Document No. 12 passed in mid-2001, which stated clearly that direct elections of township governments do not accord with the PRC Constitution and the Organic Law on Local People's Congresses and Local Governments. Since then, there has been obvious regression in terms of democratic practice in those places where local authorities started direct township elections in the late 1990s. In other townships, plans to introduce such elections have been frozen for the time being. However, this has not changed the determination of 
local governments and Party branches in many provinces to prepare for the direct ballot and to try it out at the appropriate time. How do we interpret this phenomenon-and what may be its consequences for Communist rule in China in the long term?

Township elections

11 As already pointed out, the leadership of the $\mathrm{CP}$ has tolerated experiments with direct township elections in various parts of the country, although these elections are officially considered unconstitutional and seem to have come to a halt since the passing of Party Document No. 12 in mid-2001, mentioned above. The townships ${ }^{21}$ stand at the lowest level of government with the system of people's congresses. According to the PRC Constitution, it is the members of the township people's congresses who elect the respective township governments. By introducing direct elections, however, the township people's congress is circumvented. ${ }^{22}$ Also, by electing their township heads, the rural population gets additional leverage-at least theoretically-to fight back the CP's influence in local politics. This raises the question as to why the provincial and local branches have actually become a motor of the direct ballot at this level in some parts of China.

12 As a matter of fact, the reasons are the same as in the case of the introduction of direct village elections in the late 1980s: enhancement of administrative efficiency by the recruitment of new functional elites; stabilisation of the political system by more political participation; and consequently, reconsolidation of Party legitimacy in the countryside. ${ }^{23}$ However, the township ballot is also a reaction to a structural problem that has been caused by the consequences of direct village elections in recent years. Today, many township governments face a politicised peasantry that is resisting the policies coming down from this level, especially with respect to taxation and off-therecord fees. In many cases, the peasants force their elected village committees to take the lead in these confrontations. Also, township cadres find it more difficult these days to interfere in the villages' administration, for instance by influencing the nomination of village committee candidates before elections or by exerting pressure on the village committees thereafter. At the same time, the township governments themselves feel the pressure coming down from the county governments, as they have to comply with the policy guidelines handed down from this level. This pressure is strengthened by a high degree of township fiscal dependence on the counties, inducing the townships to fight for a bigger share of the village financial cake in order to gain more economic autonomy vis-à-vis the counties. Consequently, the township governments become 'sandwiched' between the villages and the counties, which undermines their authority. ${ }^{24}$ The introduction of direct township elections is seen by many township cadres and local Party officials as the only way out of this situation..$^{25}$

13 This development makes many observers believe that the same pressure will soon be felt at the county level, too, so that in the end direct elections have to be introduced successively at the county, provincial and, finally, national level. From that perspective, starting direct village elections has sown the seeds for a gradual breach of the CP's power monopoly, ending up in full-scale parliamentary democracy. The question is, however, if this teleology grasps what is happening in the Chinese countryside today. Do we really face the beginning of a democratisation process from the 'bottom-up' in those places where direct elections have become genuinely meaningful? At this point, a closer look has to be given to the CP's endeavours to counter the danger of being 
marginalised in those elections. As a matter of fact, the Party is not ready to give up its political supremacy in the process at all, but tries to have a direct ballot without losing control over it. Contrary to the 'functional optimists' and much Fukuyaman-Hegelian historical thinking, I argue here that these endeavours are rather successful so far. The CP's cautious approach of implementing (or tolerating) direct elections and more intraParty accountability may indeed help it to generate enough legitimacy for proceeding with one-party rule for a long time to come-especially if the Party manages to go ahead with economic reforms successfully at the same time.

How have direct township elections been implemented so far? The following is a brief account of the most important developments since the beginning of this experiment in the late 1990s: It all started in Nancheng township of Qingshen county in Sichuan province, where provincial authorities had encouraged lower level Party branches to experiment with direct township elections since early 1998. ${ }^{26}$ Preparations for this move were kept completely secret. Candidates running for the two posts of township head and deputy head were nominated by the haixuan method ${ }^{27}$ in late November 1998. The Nancheng Party committee and the county organisation department then screened those candidates down to three (out of eight) for the post of township head and another eight (out of 22) for the position of deputy head. These nominees made brief speeches in a primary school to village cadres and villager representatives of Nancheng township who were asked to tell the villagers about the selected nominees and their respective agendas afterwards. On November 28th, a primary election was held among the eligible population in Nancheng, producing two final candidates for the post of township head and another four candidates for deputy head. The final vote took place one week later, on December 5th. No public campaigning was allowed in the meantime. This was indeed the first direct election of a township head in the PRC. Its results were confirmed by the township people's congress immediately after the election. The whole process became public only in early 2001 .

Almost at the same time as the Nancheng ballot gained steam, the Party committee of Shizhong district in Suining municipality, also Sichuan province, also started to implement direct township elections. ${ }^{28}$ Shizhong's leaders first adopted a method of 'public recommendation and selection' (gongtui gongxuan), which had been promoted by the CP organisation committee of Sichuan province in order to enhance the quality of cadre recruitment. Starting in Baoshi town of Shizhong district in mid-1998, candidates were nominated by the haixuan method (or nominated themselves) before undergoing screening by a civil service-type examination. Only two out of 69 candidates were disqualified from the election of township head during this process. Thereafter, the remaining 67 candidates had to face a selectorate of all town congress deputies, village Party secretaries, village committee directors and village small group leaders, who chose the official candidates by a secret and openly counted ballot. Encouraged by the positive response to the open selection process in Baoshi town by the provincial authorities, Shizhong leaders then went on to conduct two open selections of Party secretaries in Dongchan town and Lianhua town and another open selection of township head candidates in Hengshan town. These experiences paved the way for the famous Buyun ballot in late 1998 (see below) ${ }^{29}$.

Besides the 'public recommendation and selection' method applied in Nancheng, other procedures have been introduced to make township elections more democratic in recent years. In Zhuoli township of Linyi county, Shanxi province, a public opinion poll 
was conducted in April 1999 to grade the three official candidates for township head, deputy head and township Party secretary. Each of them had to gain an approval rating of at least $60 \%$ (the threshold was later lowered to $50 \%$ ) to sustain the candidacy. One day before the poll, the candidates-all incumbents-had to present work reports to a selectorate of village and township administration and Party officials, representatives of village committees and villagers. This meeting was transmitted to the township's villages by the county TV station. After the results of the poll had been announced, the township people's congress officially elected the successful incumbents into office again ${ }^{30}$.

17 In the townships of Sunzhao and Fogesi of Xincai county in Henan province, candidates for township head and deputy were nominated by the eligible population through the haixuan method in early 2000. These nominees then underwent screening by the Party committee of Xincai county, which reduced the number of candidates to seven and eight respectively. Campaign speeches were delivered to a selectorate of villager representatives that chose three official candidates for both posts in each township by a recommendation vote. As in the case of Zhuoli, the people's congresses of both townships then elected the new office-holders ${ }^{31}$.

Quite different was the procedure chosen in Dapeng township of Longgang district in Shenzhen. In January 1999, the authorities organised a 'recommendation vote' (tuijian toupiao) to produce preliminary candidates for township head. All nominees, who achieved more than 100 votes (six altogether, of whom one was later disqualified because he was more than 50 years old) entered the second round, which was a hearing before a selectorate of 1,068 party and township officials and villager representativesabout one-fifth of all eligible voters in the township. ${ }^{32}$ After campaign speeches were delivered by the five nominees, the selectors cast a vote of public assessment (minyi ceping piao) to determine the final candidates. The winning candidate was then chosen by the Election Committee to be presented to the township people's congress for formal election (xuanju piao). ${ }^{33}$

International attention on China's experiment with direct township elections was raised by the above-mentioned first direct township election in Buyun, a small township of 16,000 residents, in December 1998. Candidates had to gather 30 signatures of eligible township residents to ensure their nomination. ${ }^{34} \mathrm{~A}$ limited primary then winnowed down the number of contenders to 15 . Thereafter, a selectorate of 162 village and township officials ${ }^{35}$ called the 'Joint Electoral District Conference' (xuanju lianxi huiyi) chose two of the running 15 candidates by secret ballot. These two candidates, none of whom enjoyed township backing, had to compete in direct elections held on December 31st, after a week of campaigning and public questioning. They were joined by a nominee of the Buyun Party Committee, who could join the final round directly on the basis of a special clause in the election guidelines issued by the district authorities. This candidate, Tan Xiaoqiu, was deputy Party secretary of Buyun township at the time. He won the election by a very narrow margin of $50.19 \%$ over his two opponents. ${ }^{36} \mathrm{~A}$ couple of days later, on January 4th, 1999, Tan was confirmed by the Buyun township people's congress by a simple show of hands. Of course one could have argued that the nomination of Tan Xiaoqiu was unfair and undemocratic, since he did not have to stand in the primary. However, he might have lost the direct ballot had he had to run in the primary-but he did not. ${ }^{37}$ 

people's congress deputies supported another direct ballot whereas a report jointly issued in November 2001 by the Shizhong district people's congress and the Buyun TPC stipulated that the final candidates should be presented to the TPC for election. Anyone fulfilling the qualifying conditions of age, education, 'upright behaviour' and local residency could join the primary which produced 14 candidates (of whom two were screened out for formal reasons and two withdrew voluntarily). A 'Joint Electoral District Conference', this time consisting of 165 village and township officials and representatives, chose two final candidates by secret ballot, one of them the incumbent township head Tan Xiaoqiu. On the last day of December 2001, the second direct election for Buyun township took off and was won by Tan Xiaoqiu. The result was confirmed by the Buyun TPC some weeks later, when it officially elected Tan Xiaoqiu to the position of township magistrate ${ }^{38}$

列 township or district/county level have installed important 'security mechanisms' within all township election procedures. In no case was there an unconditioned and immediate direct ballot of a township head or government. Each election was 'filtered' through a screening process of a selectorate controlled by the Party which had the final say on those candidates who would later be qualified to run in the direct ballot. ${ }^{39}$ Obviously, it was important for the Party to bring its own preferences in accordance with the democratic vote of the people as far as possible. This was achieved by different procedural combinations of indirect and direct elements of democracy with the Party mostly being in the lead. However, all information gathered so far suggests that the township elections held under these new schemes are considered much fairer and more democratic by the population than the constitutional arrangement of local people's congresses ${ }^{40}$ electing the township governments. This shifts the attention back to my central assumption that these limited elections (in Western terms) generate substantial legitimacy for the Party and give it 'breathing space' to consolidate (and extend) its political leadership in rural China-and in the country as a whole. ${ }^{41}$

Democratic one-party rule in the PRC?

With the empirical data available so far, the following observations should be repeated at first: The implementation of direct village elections has led to a horizontalisation of power relations in rural China and more political awareness of the peasants. Consequently, the $\mathrm{CP}$ is forced to introduce additional institutional reforms, for example a more transparent and democratic recruitment of local Party cadres-to secure its leadership in the countryside. Also, it feels the pressure to introduce more democratic elements at the next administrative level, i.e. the townships, in order to pacify the 'structural conflict' between the local village committees and the township governments. First steps in this direction have been taken by local Party branches in different provinces, even if the central government has implicitly declared those experiments illegal for the time being. The question of how much legitimacy the Party has actually won by the cautious introduction of direct village and township elections is still very much underresearched. However, as the introduction of direct village elections has shown, there is reason for the Party leadership to be optimistic. In those areas where elections have been fairly well implemented and practised over a longer time and where the tension between 'civilian' and Party authority has been successfully 
mediated by more intra-Party democracy, a noticeable rise in social stability, administrative efficiency and political legitimacy for the Party has been observed.

An extension of township elections to the county level might be opportune and necessary for the CP some day. However, as to when this time will have come remains open. As has been pointed out before, the $\mathrm{CP}$ has postponed long-discussed plans of institutionalising a direct ballot at the township level for the time being, making it very difficult to proceed with electoral reforms for those local authorities who are inclined to do so. There are still other reasons, why direct county elections seem to be a long way down the road: The fiscal position of the counties is much stronger than those of the townships, making them more independent of the provinces than are the townships vis-à-vis the counties. This means that the counties are in a better position to withstand the political pressure from below in case of conflicts over policy implementation between the counties and their subordinates. First of all, the counties are able to use their financial resources and political influence to 'pacify' township leaders. Secondly, they will not instigate pressure from below by extracting too much in fees and taxes, because they do not depend on the financial transfers from the townships to the same degree as the townships depend on the villages. Therefore the counties could pass the buck back to the townships for a relatively long time-if only elections at the township level are fair and the counties do not interfere too much in township business. ${ }^{42}$

Generally speaking, there is no reason to assume that the further perfection of village elections and even the systematic introduction of direct township elections one dayboth under the roof of ongoing one-Party rule-would be considered manipulative and undemocratic by the rural population. On the contrary, these elections have been considered quite democratic, even if they did not live up to Western standards calling for the right of organisational freedom and an institutionalised multi-party system. There might be democratic legitimacy behind the wall of one-party rule. Such a 'oneparty democracy' is hardly imaginable in the West and would be flatly rejected by most Western scholars as a practicable model to generate political legitimacy in the long or even medium term. In China, however, institutional flexibility and adaptiveness of the $\mathrm{CP}$, the political economy of rural China (where political legitimacy is closely connected to economic performance and the 'wise' distribution of assets to cadres and peasants), even specific elements of political culture (preference for stability and order over participation) and the history of the PRC (giving the CP much credit for its role as an anti-colonial movement and symbol of national unity) make the idea of democracy under one-party rule an interesting point of discussion..$^{43}$

The careful rebuilding of the political system of the PRC is only one element in a dynamic and comprehensive reform process which the CP has managed impressively well over the last 25 years in terms of making its one-party rule compatible with the requirements of modernisation and functional differentiation. Nobody would question that the $\mathrm{CP}$ has suffered many ideological setbacks since the beginning of the reform era. 'Socialism with Chinese characteristics' does not reach the population at large, and the homogeneity of the Party has become cracked by regionalism, widespread corruption and various forms of local resistance against the cadre bureaucracy. But this does not necessarily mean that the $\mathrm{CP}$ will soon fail to keep pace with the reforms that it has initiated. More probably, the Party's power monopoly might possibly be upheld for a rather long time, just because it is 'contained'-albeit in a quite limited way-by 
the introduction of elements of competitive democracy in the political process: 'Limited' or 'restricted' democracy generates legitimacy, because it is more than nothing, but not too much. It might be just the right dose of democracy to balance the people's and the Party's diverging interests in terms of participation and control. This does not mean that the CP regime will never see the formation of a powerful opposition some day that might bring about a democratic transition in China. Also, a regime change from above, as in Taiwan, cannot be completely dismissed as a future option for the Communist leadership. Without the realisation of at least one of these two possibilities, Chinese democratisation 'Western-style'44 is not imaginable. More probable, however, is the long duration of the present regime which has to be investigated thoroughly with respect to its potential for institutional innovation and flexibility in order to properly understand its inherent stability and political (democratic) legitimacy. Therefore, the common optimism of modernists and functionalists with their fixation on the nascent Chinese urban middle class as the most important driving force of pluralisation and democratisation might blur the present picture of political system reform in the PRC. Taking a close look at the developments in the Chinese countryside is just as important.

\section{NOTES}

1. I want to thank Patricia Thornton, Li Lianjiang, He Baogang and Thomas Heberer for comments on earlier drafts on this article.

2.For a more recent example of such seldom 'scenario-making' see Richard Baum, 'China after Deng: Ten Scenarios in Search of Reality, in: The China Quarterly, No. 145, March 1996, pp. 153-175.

3.For more recent literature provided by the 'sceptics' and 'pessimists', see e.g. Zhao, Suisheng (ed.), China and Democracy. The Prospect for a Democratic China, LondonNew York 2000; Friedman, Edward/McCormick, Barret L. (Hg.), What If China Doesn't Democratize? Implications for War and Peace, New York 2000.

4. See e.g. the special edition of the Journal of Democracy ('Will China democratize?'), Vol. 9, No. 1, January 1998, with contributions, among others by Harry Harding, Michael Oksenberg, Robert Scalapino, Arthur Waldron and Andrew J. Nathan. Although most of these scholars are very cautious to predict a 'democratic outcome' for China any time soon, they leave not doubt in their articles that liberal democracy is possible and preconditional for further progress and stability in China. They do not think about the possibility of long-term regime stability and legitimacy within a framework of restricted democratic reforms, but see the latter, if successful, as the harbingers of fullscale regime transformation from authoritarianism to democracy. Quite representative for this epistemologic background is also the final passage in Australian-based mainland scholar He Baogang's fine study on The Democratization of China, LondonNew York 1996, p. 231: 'In conclusion, one thing is certain - that China will undertake a democratic breakthrough in the future. It is not clear what model of democracy, liberal, paternalistic or popular, will be implemented in practice. However, we can be sure that 
no matter what the kind of 'Chinese character' of democratization, it will involve a general election and some degree of proceduralism. We can also be sure that the road towards democracy is going to be a long one in China, and in the end the Chinese people will be able to push China along in its historical quest for modernization and its drive to become a more liberal and democratic society.' I have dealt with the 'epistemologic optimism' in the China field in Schubert, Gunter, The China Scholar's Historical-philosophical Optimism - Some Annotations to the Debate on Political System Change in the PRC (Der geschichtsphilosophische Optimismus der Chinaforscher - Anmerkungen zur Debatte über den Wandel des politischen Systems der VR China), in: KAS-Auslandsinformationen, No. 6, 1998, pp. 4-17.

5.Take note that by 'Western research' I mean both the research of Western scholars and Chinese scholars publishing in the West - which, of course, can be strikingly different from what these Chinese scholars publish in the PRC.

6.I know that I am stretching this point a little bit, since many Western scholars have pointed in recent years at the relative stability that the new power arrangements between the party-state (both central and local) and the society have produced. However, I insist that this 'relative stability' is mainly considered a transitional phenomenon that can't survive too long. See e.g. Goldman, Merle/MacFarquar, Roderick (eds.), The Paradox of China's Post-Mao Reforms, Cambridge/Mass. 1999.

7.See, for instance, the introduction of the above-cited study by Goldman/MacFarquar: 'No matter how many campaigns are launched against corruption, without the introduction of a regulatory system, a rule of law, and an independent judiciary, and with the Party's continuing control over law enforcement, official directives against corruption produce minimal results' ('Dynamic Economy, Declining Party-State', The Paradox of China's Post-Mao Reforms, op.cit., p. 14).

8.Concerning the history of the 1987 Organic Law, see Elklit, Jorgen, The Chinese Village Committee Electoral System, in: China Information, Vol. 11, No. 4, 1997, pp. 1-13; Kelliher, Daniel, The Chinese Debate over Village Self-Government, in: The China Journal, No. 37, January 1997, pp. 63-86; Li, Lianjiang/O'Brien, Kevin J., The Struggle Over Village Elections, in: Goldman, Merle/MacFarquar, Roderick (eds.), The Paradox of China's Post-Mao Reforms, Cambridge 1999, pp. 129-144.

9.'Zhonghua renmin gongheguo cunmin weiyuanhui zuzhifa' (The Organic Law of Village Committees of the People's Republic of China), Beijing 2000 (Falü chubanshe). 10.Robinson, James, A Village Election with Chinese Characteristics, in: Taipei Journal, May 19, 2000, p. 7, quoting Zhan Chengfu of the MCA, who is in charge of the implementation of nation-wide direct elections of village committees. However, other sources hold that the figures of Chinese villages that have seen direct elections range from one third to 50 per cent only. See O'Brien, Kevin/Li, Lianjiang, Accommodating 'Democracy' in a One-Party State: Introducing Village Elections in China, in: The China Quarterly, No. 162, 2000, pp. 465-489.

11.For a general overview of the state of local-level democracy in the PRC including reports on village, township and urban neighbourhood elections which conveys a rather positive picture, see Li, Fan (ed.), Zhongguo jiceng minzhu fazhan baogao, 2000-2001 (Report on the Development of Base-level Democracy in China), Beijing 2002. 12. However, nowhere in China's existing laws are these punishments clearly stipulated. It is therefore not possible to go to court to pursue a special case, yet. See Liu, Yawei, Consequences of Villager Committee Elections in China, in: Chinese Perspectives, No. 31, September-October 2000, pp. 19-35 (31). 
these stipulations cannot be applied easily, since the PRC still lacks an election law and a corresponding court system dealing with its interpretation and application.

13.See Manion, Melanie F., The Electoral Connection in the Chinese Countryside, in: American Political Science Review, Vol. 90, No. 4, 1996, pp. 736-748; Jennings, M. Kent, Political Participation in the Chinese Countryside, in: American Political Science Review, Vol. 91, No. 2, June 1997, pp. 361-372; Shi, Tianjian, Voting and Nonvoting in China: Voting Behaviour in Plebiscitary and Limited-Choice Elections, in: Journal of Politics, Vol. 61, No. 4, November 1999, pp. 1115-1139; He, Baogang/Lang, Youxing, Xunzhao minzhu yu quanwei de pingheng. Zhejiang cunmin xuanju jingyan de yanjiu (Looking for an Equilibrium of Democracy and Authority. Study on Zhejiang Villagers' Election Experiences, Wuhan 2002.

14.See Lawrence, Susan V., Democracy, Chinese Style, in: The Australian Journal of Asian Affairs, No. 32, 1994, pp. 61-68; Li, Lianjiang/O'Brien, Kevin J., The Struggle Over Village Elections, in: Goldman, Merle/MacFarquar, Roderick (ed.), The Paradox of China's Post-Mao Reforms, Cambridge 1999, pp. 129-144,; Hu, Rong, Cunmin weiyuanhuide zizhi ji qi yu xiangzhen zhengfude guanxi (The Autonomy of the Village Committees and their Relationship to the Township governments), in: Ershiyi jiji, Nr. 50, December, 1998, pp. 133-140; He, Baogang/Lang Youxing, Cunmin xuanju dui xiangcun quanlide yingxiang (The Influence of Village Elections on Local Power), in: Xianggang shehui kexue xuebao (Hong Kong Journal of Social Sciences), No. 16, Spring 2000, pp. 99-124; Guo, Zhenglin, Cunmin xuanju houde kunhuo, douzheng yu quanli geju (Constellations of Power, War and Perplexity), paper presented at the 2nd Conference on the Construction of Village-level Self-government in the PRC (Zhongguo dalu cunji zuzhi jianshe xueshu taolunhui), Chinese University of Hongkong, March 16-17, 2001.

15.Li, Lianjiang, The Two-ballot System in Shanxi Province: Subjecting Village Party Secretaries to a Popular Vote, in: China Journal, No. 42, July 1999, pp. 103-118.

16. However, in most parts of rural China, the party secretary still is the most important power-holder, whose position is hardly shaken by village elections. See more recently e.g. Oi, Jean C./Rozelle, Scott, Elections and Power: The Locus of Decision-making in Chinese Villages, in: The China Quarterly, No. 162, June 2000, 513-539; Alpermann, Björn, 'The Post-Election Administration of Chinese Villages, in: The China Journal, No. 46, July 2001, pp.45-67; also Tsai, Lily Lee, 'Cadres, Temple and Lineage Institutions, and Governance in Rural China, in: The China Quarterly, No. 48, July 2002, pp. 1-27; Zhong Yang/Chen Jie, To Vote or not to Vote. An Analysis of Peasant's Participation in Chinese Village Elections, in: Comparative Political Studies, Vol. 35, No. 6, August 2002, pp. 686-712.

17. Once again, stability is a double-edged sword here: If the Party remedies the complaints of peasants by punishing local officials for illegal behaviour, it might win over the momentary support of the peasants. But at the same time, it then punishes its own people, suggesting to the peasants that it is on the retreat. This can have serious long-term repercussions for its rule in the countryside. See Li, Lianjiang/O'Brien, Kevin, Villagers and Popular Resistance in Contemporary China, in: Modern China, Vol. 22, No. 1, January 1996, pp. 28-61; O'Brien, Kevin J., Rightful Resistance, in: World Politics, Vol. 49, No. 1, October 1996, pp. 31-55; O'Brien, Kevin, Villagers, Elections, and Citizenship, paper presented at the 2nd Conference on the Construction of Village Selfrule Structures in China (Zhongguo dalu cunji zuzhi jianshe xueshu taolunhui), 16-17 
March, 2001, Chinese University of Hongkong; Li, Lianjiang, Elections and Popular Resistance in Rural China, in: China Information, Vol. 15, No. 2, 2001, pp. 1-19.

18.See Liu, Yawei, The Invisible War: The Role of the Party in Villager Self-Government, paper presented at the Conference on Village Self-Government in China: An Evaluation of Its Progress, 1-2 December 2000, Center for Electoral Studies, Duke University; Li, Changyin, Dangqian nongcun liangwei guanxi zhuangkuang yu fenxi (State and Analysis of the Present Relationship between the Two Committees in the Village), paper presented at the International Symposium on Villager Self-Government \& Rural Social Development in China (Cunmin zizhi yu zhongguo nongcun shehui fazhan), 2-5 September, 2001, Beijing.

19. Chinese scholars and party theoreticians spend much time to explain away this contradiction. According to their delicate reasoning, both party and village committees should respect each other's legal responsibilities and duties, and village administration should be understood as a cooperative effort. The reality of conflict is simply ignored. I have dealt with this aspect of the Chinese debate on village elections briefly in Schubert, Gunter, Village Elections in the PRC. A Trojan Horse of Democracy?, Project Discussion Paper No. 19, Institute of East Asian Studies, Gerhard-Mercator-University Duisburg, 2002.

20.Guo, Zhenglin, Jiazu, dangzhibu yu cunweihui hudongde zhengzhi fenxi (The Mutual Relationship between Clans, the Party Branches and the Villager Committees), in: Zhanlue yu guanli, No. 2, 2002, 94-104; Xiao, Tangbiao, Zongzu, xiangcun quanli yu xuanju (Clans, Township Authority and Elections), Xian 2002

21.There are about 45.000 townships in China, each of them comprising 20.000 residents and 10-20 villages on average.

22.It may be added here that the constitution stipulates the direct election of members of the township and county people's congresses. However, the CP interferes by various methods in the nomination process of these elections, so that they can hardly be called direct.

23. He Baogang and Lang Youxing have correctly pointed out that the conceptual rationale behind the politics of direct township elections is paternalism or paternalistic democracy: 'Township election aims to achieve unity and consensus, not conflict and dispute. It aims to maximize public interest, not personal ones. For central leaders, township elections offer a platform for change and redistribution of local powers without any disruption to the authority of the centre. (...) Township democracy must strike a balance between authority and freedom, and central interest and local interests.' See He, Baogang/Lang Youxing, China's First Direct Elections of the Township Head: A Case Study of Buyun, in: Japanese Journal of Political Science, Vol, 2, No. 1, pp. 1-22 (2).

24.This is certainly far less true for well-off townships like, for instance, in the Shenzhen Special Economic Zone (some of which this author has visited). These townships are very often not only disproportionately big (Shajing township in northwestern Shenzhen having more than 450.000 residents, of which, however, 390.000 are migrant workers), but also very powerful and both financially and politically more or less independent from their higher level district and city governments.

25.Li, Fan, Buyun xiang shi Zhongguo zhengzhi tizhi gaige de 'Xiaogang cun' ma? (Is Buyun Township the 'Xiaokang' of Political Reforms?), in: Zhongguo shehui daokan, No. 2, February 1999, pp. 14-17; Wu, Shiyi, Du Runsheng shuo: nongmin ying biancheng ge 
'ziyouren' (Du Runsheng Says: The Peasants Should Become 'Free Men'), in: Beijing guancha, No. 1, January 1999, p. 12. Direct township elections have also been promoted by leading figures of the Chinese central government in the past. For example, former prime minister Zhu Rongji said at a press conference in March 2000 that he supported the extension of direct elections to the next levels of government 'as soon as possible' (People's Daily, March 16th, 2000, p. 1). Also, it might be worth mentioning that Deng Xiaoping himself has talked about direct elections up to the national level, even if that was only to happen in the mid-21st century. Certainly enough, Deng said nothing about the abolition of Communist one-party rule in such a system. See Deng, Xiaoping, Deng Xiaoping wenxuan (Selected Works of Deng Xiaoping), Vol. 3, Beijing 1993, pp. 220-221. 26.Details of the Nancheng election and the other township elections described below are - if not indicated otherwise - mainly drawn from Li, Lianjiang, The Politics of Introducing Direct Township Elections in China, in: The China Quarterly, No. 171, September 2002, pp 704-723 and the Report of The Carter Center's Fourth Observation of Chinese Village Elections (Carter Center Report 2000), January 4-13, 2000 (www.cartercenter.org.).

27.Haixuan, 'voting out of the depth of the sea', means that every voter can nominate a candidate he/she feels suitable, mostly by handing in a peace of paper with the candidate's name on it.

28.It is interesting to mention the reasons for the Shizhong party committee's initiative. It was coming after the bankruptcy of a fabric that had been constructed with funds provided by government employees and after the dismissal of the party secretary and township head of Baoshi township (belonging to Shizhong district), who had embezzled public funds. Both incidents discredited the Shizhong party committee, so that the venture on direct township elections was an obvious effort to regain political legitimacy (Li, The Politics of Introducing Direct Township Elections in China, op.cit, p. 710).

29.Li, The Politics of Introducing Direct Township Elections in China, op.cit, p. 711; See also Li Fan/ Shou Huisheng/Peng Zongchao/Xiao Lihui, Chuangxin yu fazhan (Innovations and Development), Beijing 2000.

30.The polling was done through a ballot, though secret balloting was not enforced. There were reports of manipulations and outright cheating seemed to have taken place at least in some cases. See Xiao Qun, Xuan 'xiangguan' baixing xian toupiao (The Ordinary People Vote First for Their Township Cadres), in: Xiangzhen luntan, No. 5, May 1999, pp. 4-6; Carter Center Report 2000, op.cit.; see also Liu, Yawei, Elections of Township/Town Magistrates in Buyun, Dapeng and Linyi, 1998-1999, 1 January 1999 (www.cartercenter.org).

31.Wang Xin, Shou pi 'minxuan xiangguan' zai Henan chansheng (The First Directly Elected Township Cadres in Henan), in: Xinhua ribao, April 2nd 2000, p.C4.

32.It remains unclear, however, why there were only 5.284 eligible voters within a population of permanent township residents of 171.000 and a temporary population of 800.000. See Cheng, Joseph Y.S., Direct Elections of Town and Township Heads in China: The Dapeng and Buyun Experiments, in: China Information, Vol. 15, No. 1, 2001, pp. 104-137, here 117.

33.For details of the Dapeng election see Cheng, Direct Elections of Town and Township Heads in China, op.cit.; Liu, Yawei, Elections of Township/Town Magistrates in Buyun, Dapeng and Linyi, 1998-1999, op.cit.; Shi, Weimin, Gongxuan yu zhixuan (Public and Direct Voting), Beijing 2000, pp. 411-427; Li, Fan/Shou, Huisheng/Peng, Zongchao/Xiao, 
Lihui, Chuangxin yu fazhan (Innovation and Development), Beijing 2000, pp. 91-96; Huang, Weiping, Zhongguo jiceng minzhu fazhan de zuixin tupo (The Latest Breakthrough in the Development of China's Grassroots Democracy), Beijing 2000. Contrary to the second direct ballot for township head in Buyun in 2001, the Dapeng experiment was not repeated when new elections where due three years later. The township head was once again chosen and elected by the local TPC (personal information to the author by a scholar of Shenzhen University, November 2002). 34. However, party-affiliated candidates and candidates nominated by mass organisations were excluded from this stipulation. Also, political parties could nominate candidates from the entire Shizhong district.

35.All secretaries of village and residents' committees party branches, heads of village and residents' committees, clerks of village committees, heads of villager groups, members of the Buyun party committee and government, and members of the Election Committee. See Cheng, Direct Elections of Town and Township Heads in China, op.cit., p. 124.

36.According to election regulations, the winning candidate had to gather more than 50 per cent of the vote. Actually, Tan Xiaoqiu won 3.130 votes against 1.995 gained by his strongest opponent, which makes his victory look much stronger than reported. 37. The most important reason for Tan's victory was often said to be his access to more plentiful financial resources to campaign and to more logistical support provided by the township authorities. However, other authors have pointed out, that Tan was finally more convincing to the voters by laying out a stringent strategy of economic development promotion for the township and by bringing in his high-level contacts established during his long time as a local politician. See Manion, Melanie, Chinese Democratization in Perspective: Electorates and Selectorates at the Township Level, in: The China Quarterly, No. 163, September 2000, pp. 764-782, here pp. 781-82; Li Fan, Jiceng ganbu de xuanju ji qi yiyi. Sichuan Suiningshi Shizhong qu ganbu gongxuan de kaocha (Elections of local cadres and their significance. Investigation of the public cadre election in Shizhong district of Suining city in Sichuan), in: Zhongguo shehui daokan, No. 5, 1999 (www.ccrs.org); see also Liu, Yawei, Elections of Township/Town Magistrates in Buyun, Dapeng and Linyi, 1998-1999, op.cit.

38.Li, Changping, Muji Buyun huanjie xuanju (Eyewitnessing the falling-due Buyun election), in: Zhongguo gaige, No. 1, 2000, pp. 22-23; China and the World Institute, Buyun xiang liangci xuanju de gaikuang, bijiao ji sikao (Reflection on, comparison and brief account of the two elections in Buyun township), www.world-and-china.com/ 03/0302091203.htm.

39. However, these selectorates were at least partly composed of directly elected villager representatives.

40.The Communist Party is also trying to reform the nomination process for candidates of the local people's congresses. According to the PRC constitution, congress members at the township and county levels are directly elected by the eligible population. However, the $\mathrm{CP}$ branches so far tightly control the nominations. Only recently, they have started with experiments of more competitive screening procedures and choice that pretty much resemble those described for elections of township governments in this article. For details, see Manion, Chinese Democratization in Perspective:

Electorates and Selectorates at the Township Level, op.cit.

41.It is interesting to note at this point Melanie Manion's (and other's) verdict that the 1998 Buyun election was a complete failure for the party authorities, since their 
candidate, Tan Xiaoqiu, could hardly win against a non-party competitor. But why not interpreting the results the other way round: As Tan survived the elections, victory has made him a much stronger township head than anyone else who would have been put in office by the former indirect ballot of the local people's congress? As a matter of fact, the Buyun ballot gave democratic legitimacy to a Communist cadre who would later turn out to be a very efficient and responsible township head who could easily secure re-election.

42.I admit that this line of argument is tentative at best, since research on the political economy of township-county relations is very scant.

43.I fully realize that many readers will take issue with my definition of democracy. It is certainly questionable to call a system of fair and competitive elections at the local level under the accepted parameters of one-party rule democratic, even if naming it a restricted democracy 'Chinese style'. Also, I believe myself that organizational freedom and a free press are core ingredients of any definition of democracy. However, much depends on the people's perception of what is democratic and what is not. In that sense, there might be some justification for the Communist Party to speak of such a thing, if only it has the support of the people (which is to test, though).

44.By 'democratization Western-style', I foremost mean a multi-party system at all levels of government. 